\title{
Study On The Relationship Between Ownership Structure And Corporate Performance: Evidence From Chinese Companies Listed On The GEM Board
}

Qiaowen Zhang, Stellenbosch University, South Africa

Pierre Erasmus, Stellenbosch University, South Africa

\begin{abstract}
The study on which this article reports, analyzed the current situation of ownership structure and corporate performance based on the panel data of 153 companies listed on the Growth Enterprises Market (GEM) board from 2010 to 2012 and explored the mechanism of companies' ownership structure to corporate performance with multiple regressions. The results show that tradable shares, state-owned shares and managerial shares have a negative correlation with corporate performance, and that there is a significant quadratic non-linear relationship between tradable shares and corporate performance while legal-person shares are not significantly related to corporate performance. We also found that the shareholding ratio of the top ten largest shareholders has a significantly positive correlation with corporate performance but we failed to find any significance for the largest shareholder and the $Z$ index.
\end{abstract}

Keywords: Ownership Structure; Corporate Performance; GEM Board; Corporate Governance

\section{INTRODUCTION}

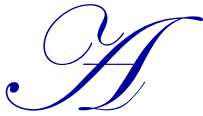
s a newly emerging force in Chinese capital markets, the GEM board has received a lot of attention. The GEM board of the Chinese stock market was set up in 2009, and by the end of 2013, a total of 355 companies were listed on the board ${ }^{1}$. By the end of 2013, the total market value of the GEM board had risen to RMB 1.5 trillion, and there are more than 20 enterprises whose market values exceed billions of $\mathrm{RMB}^{2}$. Although the GEM board has not been considered as the leading player in the Chinese stock market, going public on the GEM board is becoming an important approach for the initial public offering (IPO) of growth enterprises, a breeding base for strategic emerging industries, and a financing platform for high- and new-tech enterprises, which have a significant influence on the Chinese structural transformation of the economy and upgrading of the industrial structure.

Before going public, the majority of companies listed on the GEM board were family enterprises with concentrated equity $^{3}$. Stock rights began to decentralize once listed and the separation of ownership and control resulted in a series of problems concerning ownership structure and corporate governance, e.g., agency problems (Du \& Liu, 2002). As a form of structural arrangement, ownership structure is an important part of corporate governance, which will ultimately influence corporate performance. Relatively little research has been conducted on ownership structure and the corporate performance of Chinese companies listed on the GEM board, with the majority of previous research focused on the main board and the small and medium-sized enterprise (SME) board. However, the

\footnotetext{
${ }^{1}$ See Shenzhen Stock Exchange (SZSE) official website, http://www.szse.cn/main/chinext/

${ }^{2}$ See China Stock Market and Accounting Research (CSMAR) database

${ }^{3}$ China Securities Times indicates that over eighty percent of listed companies on the GEM board are family controlled companies, see http://kuaixun.stcn.com/2013/0811/10668510.shtml
} 
GEM board possesses its own characteristics and is different from the main and SME boards in many aspects, e.g. scale, industry distribution and ownership structure, thereby necessitating conducting a study regarding ownership structure and corporate performance of companies listed on the GEM board. Hence, the current study will not only enrich the relevant theory, but will also offer recommendations for good corporate governance practices, assist companies listed on the GEM board with their development and growth, and promote the development of a multilevel capital market and optimize its structure.

\section{RESEARCH QUESTIONS AND HYPOTHESIS}

Ownership structure is defined along two dimensions, namely ownership mix and ownership concentration (Gursoy $\&$ Aydogan, 2002). The exploration of the relationship between ownership structure and corporate performance has been the focus of scholars worldwide, initiated by Berle and Means's research in this field following the Great Depression (Berle \& Means, 1932) and continuing beyond Jensen and Meckling formally discussing the relationship between the two concepts (Jensen \& Meckling, 1976). Even when considering the subsequent decades' exploration, no generally accepted conclusion has yet been reached. Some researchers (e.g. Anderson \& Reeb, 2003; McConnell \& Servaes, 1990; Pedemen \& Thomsen, 1999) hold that ownership structure has an effect on corporate performance, but still many studies (e.g. Domsetz \& Villalonga, 2001; Holderness \& Sheehan, 1988; Wahla, Shah, \& Hussain, 2012) fail to find a relationship between ownership structure and corporate performance. Chinese scholars (e.g. Bai, Liu, Lu, Song, \& Zhang, 2005; Chen \& Xu, 2001; Liu \& Wang, 2000; Sun \& Huang, 1999; Tan, He, \& Ma, 2011) have also conducted extensive research on this subject, most of which is focused on companies that are listed on the main board and the SME board, since the GEM board is still considered a new development in China. As a result, conducting research on the GEM board became both important and urgent since it has already become an indispensable part of the Chinese multi-level capital market.

This article attempted to answer the following two research questions to achieve the goal of the study:

1) Is there a relationship between ownership structure and the corporate performance of companies listed on the GEM board?

2) What is the specific relationship between different variables of ownership structure and corporate performance of companies listed on the GEM board?

\subsection{Ownership Mix and Corporate Performance}

Ownership mix is concerned with the identity of a company's major shareholder, who could have tradable shares, state-owned shares and legal-person shares considering the Chinese context (Xu \& Wang, 1999). Furthermore, people at management level of companies listed on the GEM board often hold majority shares, so it is necessary to take managerial shares into consideration as well.

Theoretically, according to price signals of the stock market and takeover mechanisms, the stronger stock liquidity is, the more beneficial it is to risk diversification and the effectiveness and efficiency of corporate financing. However, in reality, as the Chinese capital market is not fully developed, most tradable shareholders are individual investors and their ownership is too dispersive and speculative to get involved in corporate governance. Free-rider problems frequently occur among minority shareholders. Thus, the high proportion of tradable shares may have a negative effect on corporate governance rather than making corporate governance more efficient (Chen \& Xu, 2001; $\mathrm{Xu} \& \mathrm{Hu}, 2006)$. In addition, a high proportion of tradable shares is likely to disperse decision-makers' control, which is not beneficial to informed decision-making (Du \& Liu, 2002).

With their strong political character and political agendas, state-owned shares, on the one hand, will lead to a more complicated agency relationship and higher agency cost (Du \& Liu, 2002) so that managers can take advantage of weak control of ownership to achieve insider control. Xu and Wang (1999) report that the more state-owned shares exist, the worse corporate performance is (see also Wang \& Xu, 2009; Yan, 2009). However, it cannot be denied that state-owned shares have a positive side, and some scholars suggest that the participation of state-owned shares can bring extra welfare to companies (Liu, 2004; Liu, Huang, Tse, \& He, 2011). On the other hand, unnecessary intervention has a negative influence on operators' autonomy so their enthusiasm is weakened. As for companies on 
the GEM board, which are innovation-oriented, there is no doubt that state-owned shareholders' involvement will affect the decision-making and innovation of operators, which will have adverse effects on listed companies.

There are obvious advantages for legal-person shareholders. Compared with individual shareholders, legal-person shareholders are equipped with more professional knowledge, abundant experience and better developed information channels (Su \& He, 2012), so that the free-rider problem can be avoided to some extent. Compared with state-owned shareholders, legal-person shareholders have no political pressure and agendas and can perform better with corporate supervision and management ( $\mathrm{Su} \& \mathrm{He}, 2012$ ). Prior research (e.g. Liu, Huang, Tse, \& He, 2011; Yu, 2001) reports positive comments regarding the relationship between legal-person shares and corporate performance. Scholars believe legal-person shareholders have good self-control and are stable - their controllable investment motivation not only results in their active involvement, but the incentive to conduct corporate supervision to improve governance efficiency, and the stability of their shareholding results in long-term operational behavior, which is beneficial to a company's development (Liu, 2000; Liu, Huang, Tse, \& He, 2011; Zhang, 2000).

At present, more and more enterprises encourage management to participate in corporate governance, like shareholders, by means of stock incentives, which can contribute to Management's interests being entwined with those of shareholders (Cornett, Marcus, \& Tehranian, 2008; Jensen \& Meckling, 1976; Li \& Wu, 2010). Hence, the adverse selection of corporate performance resulting from conflicts of interests between management and shareholders can be avoided to some extent. The results of existing research on the role top management played in corporate performance remains inconclusive. As for the current situation in China, some professional managers have problems regarding their fiduciary duty, and when management holds low levels of shareholding, their objectives still will not keep in line with corporate interest (Guglar, Mueller, \& Yurtoglu, 2004). A high level of managerial shareholding, in contrast, will make it more possible for managers to expropriate corporate interest (Fama \& Jensen, 1983; Switzer, 2007; Wang \& Xu, 2009). Due to moral deficiency and a lack of effective supervision, managers with shares may sacrifice other shareholders' interest for their own. Thus, managerial shares in listed companies on the GEM board may lead to tunneling behavior instead of positive convergence, that is, the higher the proportion of managerial shares, the more opportunities managers have to abuse power for personal gain and to damage corporate performance (Xu \& Wang, 2000).

Based on the preceding discussion, the following hypotheses were developed for the current study:

H1.1: The ratio of tradable shares has a negative correlation with corporate performance

H1.2: The ratio of state-owned shares has a negative correlation with corporate performance

H1.3: The ratio of legal-person shares has a positive correlation with corporate performance

H1.4: The ratio of managerial shares has a negative correlation with corporate performance

\subsection{Ownership Concentration and Corporate Performance}

Currently, there is no generally accepted conclusion about the effects of ownership concentration or ownership separation on corporate performance. Some research reports that there is no significant relationship between ownership concentration and corporate performance (Fernandez \& Gomez, 2002; Liu, 2004; Yu, 2001). In contrast, several scholars (e.g. Gorton \& Schmid, 2000; Wang \& Xu, 2009) point out that ownership concentration is beneficial to corporate performance. Those enterprises with high ownership concentration usually have higher profits than those with diffused ownership (Shleifer \& Vishny, 1986), and shareholders with a larger shareholding proportion are more capable and motivated to pursue corporate value maximization. Thomsen and Pedersen (2000) find that ownership concentration has a positive correlation with both shareholder wealth and corporate profit. Sun and Huang (1999) observe the important contribution to corporate governance that would result from reasonable ownership concentration and the presence of relatively controlling shareholders. Zhang (2000) suggests that there is a significant positive correlation between reasonable ownership concentration and corporate performance by studying the relationship between the top five largest shareholders and corporate performance. This is supported by Liu and Gao (2007) and Chen and Chen (2011). In addition, existing research (Lins \& Servaes, 2002; Xu \& Zhang, 
2008) shows that the degree of ownership balance is related to corporate performance and the higher the degree of balance, the more restrictions other shareholders can put on the largest shareholder, improving corporate performance to some extent.

Currently, there are three main measurements of ownership concentration: the CR index determines the cumulative percentage of shares held by the top $\mathrm{N}$ largest shareholders, while the Herfindahl index measures the sum of squared percentages of shares held by the top $\mathrm{N}$ largest shareholders. A third measure, the $\mathrm{Z}$ index, is a measurement of the degree of balance: the higher the $\mathrm{Z}$ index, the more the largest shareholder gets restricted by smaller shareholders. The current study used the CR index as a measurement of the degree of concentration, measuring both the share proportion of the largest shareholder (CR1) and the cumulative shareholding of the top ten largest shareholders (CR10). The study also adopted the $\mathrm{Z}$ index to represent the cumulative proportion of shares held by the secondlargest to tenth-largest shareholders, relative to the shareholding of the largest shareholder.

Based on the analysis above, the study formulated the following hypotheses:

H2.1: The CR1 index has a negative correlation with corporate performance

H2.2: The CR10 index has a positive correlation with corporate performance

H2.3: The $\mathrm{Z}$ index has a positive correlation with corporate performance

\section{RESEARCH METHODOLOGY}

The hypotheses developed in the previous section are used to analyze the relationship between ownership structure and corporate performance. In order to test the hypotheses, eight models are established and balanced panel data is employed. In this part of the study, details about the data are provided and the six models used to assess the relevant relationships are introduced.

\subsection{Sample and Data Sources}

The sample consisted of 153 companies, which were listed on the GEM board of the Shenzhen Stock Exchange that went public during 2009 and 2010. The data for these companies for the three-year period 2010-2012 was extracted from the CSMAR database. Hence, the data used in the current study can be defined as "secondary data". A balanced panel data methodology was applied to analyze the relationship between ownership structure and corporate performance, with 153 companies and 459 observations included in the statistical models used for analysis.

\subsection{Variable Definition}

The variables in this study consisted of corporate performance variables, ownership structure variables and control variables. The definitions of the variables are provided below:

(1) Corporate performance. Common measurements used in previous research (e.g. Brown \& Caylor, 2009; Demsetz \& Villalonga, 2001; McConnell \& Servaes, 1990; Xu \& Zhang, 2008) included Tobin's Q ratio, which is problematic to estimate, and return on equity (ROE), which is often influenced by earnings management. In an attempt to address these limitations, ROA was employed in the current study as the proxy for corporate performance.

(2) Ownership structure. As mentioned above, the measurement of ownership structure reflects ownership mix and ownership concentration. Ownership mix reflects the portion of tradable shares, state-owned shares, legal-person shares and managerial shares. Ownership concentration is measured by the CR1, $\mathrm{CR} 10$ and $\mathrm{Z}$ indices.

(3) Control variables. The current study included an industry variable, company size variable and debt to asset ratio variable as control variables. 
Table1 below provides the definitions of these variables.

Table 1. Definition of variables

\begin{tabular}{l|l}
\hline \multicolumn{1}{c}{ Variables } & \multicolumn{1}{c}{ Definition } \\
\hline Dependent Variable & net income/average total assets \\
\hline \multicolumn{1}{c}{ Return on assets (ROA) } & \\
\hline Independent Variables & tradable shares/total shares \\
\hline Ratio of tradable shares (TS) & state-owned shares/total shares \\
\hline Ratio of state-owned shares (SS) & legal-person shares/total shares \\
\hline Ratio of legal-person shares (LS) & managerial shares/total shares \\
\hline Ratio of managerial shares (MS) & shares of the largest shareholder/total shares \\
\hline Ratio of the largest shareholder (CR1) & shares of top ten largest shareholders/total shares \\
\hline Ratio of top ten largest shareholders (CR10) & $\begin{array}{l}\text { cumulative shares of second to tenth-largest shareholders / } \\
\text { shares of the largest shareholder }\end{array}$ \\
\hline $\begin{array}{l}\text { Ratio of second to tenth largest shareholders to the largest } \\
\text { shareholder (Z) }\end{array}$ & \\
\hline Control Variables & manufacturing industry=1, others=0 \\
\hline Industry (INDUS) & log(total assets) \\
\hline Company size (SIZE) & total debt/total assets \\
\hline Debt to asset ratio (DA) &
\end{tabular}

\subsection{Model Design}

According to the hypotheses above, the current study proposed the following regression model (1):

$$
\begin{aligned}
& \mathrm{ROA}_{\text {it }}=\alpha_{0}+\beta_{1} \mathrm{TS}_{\text {it }}+\beta_{2} \mathrm{SS}_{\text {it }}+\beta_{3} \mathrm{LS}_{\text {it }}+\beta_{4} \mathrm{MS}_{\text {it }}+\beta_{5} \mathrm{CR} 1_{\text {it }}+\beta_{6} \mathrm{CR} 10_{\text {it }}+\beta_{7} \mathrm{Z}_{\text {it }} \\
& +\beta_{8} \mathrm{INDUS}_{\text {it }}+\beta_{9} \mathrm{SIZE}_{\mathrm{it}}+\beta_{10} \mathrm{DA}_{\text {it }}+\varepsilon_{\text {it }}
\end{aligned}
$$

Where:

ROA refers to corporate performance, ownership mix is represented by TS, SS, LS and MS, ownership concentration is represented by CR1, CR10 and Z, and INDUS, SIZE and DA represent control variables. $\alpha_{0}$ is the intercept, $\beta_{1}-\beta_{11}$ are regression coefficients, $\varepsilon_{i t}$ is the error term, and $i$ and $t$ represent listed company $i$ and year $t$, respectively. Model (1) was used to examine whether there is a linear relationship between ownership structure and corporate performance.

In addition, since many scholars point out that there is a quadratic nonlinear relationship between ownership structure and corporate performance (Bai et al., 2005; McConnell \& Servaes, 1990; Wu, 2002; Zhang \& Zhang, 2004), the current study also used models (2) to (6) to examine whether there is a quadratic nonlinear relationship between the ownership structure of companies listed on the GEM board and their corporate performance by incorporating $\mathrm{CR} 1 \times \mathrm{CR} 1, \mathrm{TS} \times \mathrm{TS}, \mathrm{SS} \times \mathrm{SS}, \mathrm{LS} \times \mathrm{LS}$ and $\mathrm{MS} \times \mathrm{MS}$.

$$
\begin{aligned}
& \mathrm{ROA}_{\text {it }}=\alpha_{0}+\beta_{1} \mathrm{TS}_{\text {it }}+\beta_{2} \mathrm{SS}_{\text {it }}+\beta_{3} \mathrm{LS}_{\text {it }}+\beta_{4} \mathrm{MS}_{\text {it }}+\beta_{5} \mathrm{CR} 1_{\text {it }}+\beta_{6} \mathrm{CR} 10_{\text {it }}+\beta_{7} \mathrm{Z}_{\text {it }} \\
& +\beta_{8}\left(\mathrm{CR} 1_{\mathrm{it}} \times \mathrm{CR} 1_{\mathrm{it}}\right)+\beta_{9} \mathrm{INDUS}_{\mathrm{it}}+\beta_{10} \mathrm{SIZE}_{\mathrm{it}}+\beta_{11} \mathrm{DA}_{\mathrm{it}}+\varepsilon_{\mathrm{it}} \\
& \mathrm{ROA}_{\text {it }}=\alpha_{0}+\beta_{1} \mathrm{TS}_{\text {it }}+\beta_{2} \mathrm{SS}_{\text {it }}+\beta_{3} \mathrm{LS}_{\text {it }}+\beta_{4} \mathrm{MS}_{\text {it }}+\beta_{5} \mathrm{CR} 1_{\text {it }}+\beta_{6} \mathrm{CR} 10_{\text {it }}+\beta_{7} \mathrm{Z}_{\text {it }} \\
& +\beta_{8}\left(\mathrm{TS}_{\mathrm{it}} \times \mathrm{TS}_{\mathrm{it}}\right)+\beta_{9} \mathrm{INDUS}_{\mathrm{it}}+\beta_{10} \mathrm{SIZE}_{i \mathrm{t}}+\beta_{11} \mathrm{DA}_{\mathrm{it}}+\varepsilon_{\mathrm{it}} \\
& \mathrm{ROA}_{\text {it }}=\alpha_{0}+\beta_{1} \mathrm{TS}_{\text {it }}+\beta_{2} \mathrm{SS}_{\text {it }}+\beta_{3} \mathrm{LS}_{\text {it }}+\beta_{4} \mathrm{MS}_{\text {it }}+\beta_{5} \mathrm{CR} 1_{\text {it }}+\beta_{6} \mathrm{CR} 10_{\text {it }}+\beta_{7} \mathrm{Z}_{\text {it }} \\
& +\beta_{8}\left(\mathrm{SS}_{\mathrm{it}} \times \mathrm{SS}_{\mathrm{it}}\right)+\beta_{9} \mathrm{INDUS}_{\mathrm{it}}+\beta_{10} \mathrm{SIZE}_{\mathrm{it}}+\beta_{11} \mathrm{DA}_{\mathrm{it}}+\varepsilon_{\mathrm{it}} \\
& \mathrm{ROA}_{\text {it }}=\alpha_{0}+\beta_{1} \mathrm{TS}_{\text {it }}+\beta_{2} \mathrm{SS}_{\text {it }}+\beta_{3} \mathrm{LS}_{\text {it }}+\beta_{4} \mathrm{MS}_{\text {it }}+\beta_{5} \mathrm{CR} 1_{\text {it }}+\beta_{6} \mathrm{CR} 10_{\text {it }}+\beta_{7} \mathrm{Z}_{\text {it }} \\
& +\beta_{8}\left(\mathrm{LS}_{\mathrm{it}} \times \mathrm{LS}_{\mathrm{it}}\right)+\beta_{9} \mathrm{INDUS}_{\mathrm{it}}+\beta_{10} \mathrm{SIZE}_{\mathrm{it}}+\beta_{11} \mathrm{DA}_{\mathrm{it}}+\varepsilon_{\mathrm{it}} \\
& \mathrm{ROA}_{\text {it }}=\alpha_{0}+\beta_{1} \mathrm{TS}_{\text {it }}+\beta_{2} \mathrm{SS}_{\text {it }}+\beta_{3} \mathrm{LS}_{\text {it }}+\beta_{4} \mathrm{MS}_{\text {it }}+\beta_{5} \mathrm{CR} 1_{\text {it }}+\beta_{6} \mathrm{CR} 10_{\text {it }}+\beta_{7} \mathrm{Z}_{\text {it }} \\
& +\beta_{8}\left(\mathrm{MS}_{\mathrm{it}} \times \mathrm{MS}_{\mathrm{it}}\right)+\beta_{9} \mathrm{INDUS}_{\mathrm{it}}+\beta_{10} \mathrm{SIZE}_{\mathrm{it}}+\beta_{11} \mathrm{DA}_{\mathrm{it}}+\varepsilon_{\mathrm{it}}
\end{aligned}
$$




\section{DATA ANALYSIS}

The study used the cross-sectional data of 153 companies listed on the GEM board for the period 2010 to 2012 for the descriptive analysis, and panel methodology to conduct regression analyses using Eviews 6.0 to estimate the models.

\subsection{Descriptive Analysis}

The descriptive statistics of the variables are displayed in Table 2 .

Table 2. Descriptive Statistics

\begin{tabular}{c|c|c|c|c|c}
\hline Variables & Obs. & Min. & Max. & Mean & Std.Dev \\
\hline ROA & 459 & -0.3685 & 0.2732 & 0.0675 & 0.0470 \\
\hline TS & 459 & 0.1000 & 0.8720 & 0.3804 & 0.1338 \\
\hline SS & 459 & 0.0000 & 0.7220 & 0.0313 & 0.1058 \\
\hline LS & 459 & 0.0000 & 0.8000 & 0.1808 & 0.2239 \\
\hline MS & 459 & 0.0000 & 0.8973 & 0.3748 & 0.2202 \\
\hline CR1 & 459 & 0.0877 & 0.6517 & 0.3355 & 0.1276 \\
\hline CR10 & 459 & 0.4008 & 0.9140 & 0.6801 & 0.0930 \\
\hline Z & 459 & 0.0396 & 5.6864 & 1.3385 & 0.9763 \\
\hline INDUS & 459 & 0.0000 & 1.0000 & 0.6600 & 0.4760 \\
\hline SIZE & 459 & 19.6570 & 22.3830 & 20.8340 & 0.5422 \\
\hline DA & 459 & 0.0126 & 0.7641 & 0.1730 & 0.1323 \\
\hline
\end{tabular}

From Table 2, we know that:

- $\quad$ Firstly, for corporate performance, the average ROA is about $6.7 \%$, indicating that companies listed on the GEM board report profitable overall performance. The large gap between minimum and maximum ROA values, however, shows the unbalanced development among the companies.

- Secondly, for ownership mix, Table 2 demonstrates that the float ratio of listed companies on the GEM board is about $38 \%$, reflecting the low liquidity of stocks. The proportion of state-owned shares is about $3 \%$, indicating the low engagement of state-owned shares in listed companies. The proportion of legalperson shares is not large and is about $18 \%$. However, the mean value of managerial shares in listed companies is about $37 \%$, which is larger than the participation found on the main board and the SME board (Hu \& Jiang, 2004; Li \& Wu, 2010; Lin, Xu, \& Tang, 2009; Tan, He, \& Ma, 2011). Thus, we concluded that having a high proportion of managerial shares is the prominent characteristic of Chinese companies listed on the GEM board.

- Lastly, for ownership concentration, the mean of the CR1 index is about 33\%. This value is lower than the average of companies listed on the main board and similar to the index for companies listed on the SME board (Kong \& Wang, 2003; She \& Hu, 2007; Wang \& Xu, 2009; Zhang \& Fang, 2009). The mean also indicates that the largest shareholder has a relative advantage in terms of the ratio of shareholding compared with other shareholders in the company. In addition, the largest shareholder has an absolute control position in $15 \%$ and a relative control position in $72 \%$ of the companies (taking a shareholding ratio $\geq 20 \%$ as criterion for relative control). Considering the ownership balance degree, the $Z$ index of more than half the enterprises is larger than one, that is, the cumulative shareholding of the second-largest to the tenth-largest shareholders present a significant check and balance on the largest shareholder. 
Table 3. Regression of Ownership Structure and Corporate Performance (ROA)

\begin{tabular}{|c|c|c|c|c|c|c|}
\hline \multirow{2}{*}{ Variables } & \multicolumn{2}{|c|}{ Model(1) } & \multicolumn{2}{|c|}{ Model(2) } & \multicolumn{2}{|c|}{ Model(3) } \\
\hline & Coefficient & Std. Error & Coefficient & Std. Error & Coefficient & Std. Error \\
\hline $\mathrm{C}$ & $\begin{array}{l}-2.9017^{* * *} \\
(-4.7637)\end{array}$ & 0.6091 & $\begin{array}{l}-2.9350^{* * *} \\
(-4.4855)\end{array}$ & 0.6530 & $\begin{array}{l}-2.9131^{* * *} \\
(-4.8319)\end{array}$ & 0.6030 \\
\hline TS & $\begin{array}{l}-0.1412^{* * *} \\
(-5.7260)\end{array}$ & 0.0247 & $\begin{array}{l}-0.1411^{* * * *} \\
(-5.7082)\end{array}$ & 0.0247 & $\begin{array}{l}-0.3549^{* * *} \\
(-3.8921)\end{array}$ & 0.0912 \\
\hline SS & $\begin{array}{l}-0.2279^{* *} \\
(-2.4004)\end{array}$ & 0.0950 & $\begin{array}{l}-0.2288^{* *} \\
(-2.3995)\end{array}$ & 0.0967 & $\begin{array}{l}-0.2055^{* *} \\
(-2.1757)\end{array}$ & 0.0944 \\
\hline LS & $\begin{array}{c}-0.0366 \\
(-1.3966)\end{array}$ & 0.0262 & $\begin{array}{l}-0.0368 \\
(-1.3986)\end{array}$ & 0.0263 & $\begin{array}{c}-0.0298 \\
(-1.1410)\end{array}$ & 0.0261 \\
\hline MS & $\begin{array}{l}-0.0649^{* *} \\
(-2.0302)\end{array}$ & 0.0320 & $\begin{array}{l}-0.0650^{* *} \\
(-2.0287)\end{array}$ & 0.0320 & $\begin{array}{c}-0.0537^{*} \\
(-1.6801)\end{array}$ & 0.0320 \\
\hline CR1 & $\begin{array}{c}-0.3724 \\
(-0.5391)\end{array}$ & 0.6909 & $\begin{array}{l}-0.1502 \\
(-0.0875)\end{array}$ & 2.2652 & $\begin{array}{c}-0.2614 \\
(-0.3815)\end{array}$ & 0.6853 \\
\hline CR10 & $\begin{array}{l}0.1779^{* * *} \\
(3.1170)\end{array}$ & 0.0571 & $\begin{array}{l}0.1781^{* * *} \\
(3.1126)\end{array}$ & 0.0577 & $\begin{array}{l}0.1675^{* * *} \\
(2.9574)\end{array}$ & 0.0567 \\
\hline $\mathrm{Z} 10$ & $\begin{array}{c}-0.0236 \\
(-1.3388)\end{array}$ & 0.0176 & $\begin{array}{c}-0.0233 \\
(-1.3091)\end{array}$ & 0.0181 & $\begin{array}{c}-0.0182 \\
(-1.0375)\end{array}$ & 0.0176 \\
\hline $\mathrm{CR} 1 \times \mathrm{CR} 1$ & & & $\begin{array}{l}-0.3110 \\
(-0.1415)\end{array}$ & 3.4129 & & \\
\hline $\mathrm{TS} \times \mathrm{TS}$ & & & & & $\begin{array}{l}0.2839^{* *} \\
(2.4319)\end{array}$ & 0.1167 \\
\hline \multicolumn{7}{|l|}{$\mathrm{SS} \times \mathrm{SS}$} \\
\hline \multicolumn{7}{|l|}{$\mathrm{LS} \times \mathrm{LS}$} \\
\hline \multicolumn{7}{|l|}{$\mathrm{MS} \times \mathrm{MS}$} \\
\hline SIZE & $\begin{array}{l}0.1521^{* * *} \\
(5.2787)\end{array}$ & 0.0288 & $\begin{array}{l}0.1520^{* * *} \\
(5.2637)\end{array}$ & 0.0289 & $\begin{array}{l}0.1523^{* * *} \\
(5.3396)\end{array}$ & 0.0285 \\
\hline DA & $\begin{array}{l}-0.4080^{* * *} \\
(-6.3761)\end{array}$ & 0.0640 & $\begin{array}{l}-0.4083^{* * * *} \\
(-6.3638) \\
\end{array}$ & 0.0640 & $\begin{array}{l}-0.4017^{* * *} \\
(-6.3359)\end{array}$ & 0.0634 \\
\hline INDUS & \multicolumn{2}{|c|}{ Yes } & \multicolumn{2}{|c|}{ Yes } & \multicolumn{2}{|c|}{ Yes } \\
\hline Adj. $R_{2}$ & \multicolumn{2}{|c|}{0.5440} & \multicolumn{2}{|c|}{0.5420} & \multicolumn{2}{|c|}{0.5533} \\
\hline F-value & \multicolumn{2}{|c|}{$3.9303^{* * *}$} & \multicolumn{2}{|c|}{$3.8901^{* * *}$} & \multicolumn{2}{|c|}{$4.0238^{* * *}$} \\
\hline D-W & \multicolumn{2}{|c|}{2.2266} & \multicolumn{2}{|c|}{2.2293} & \multicolumn{2}{|c|}{2.2113} \\
\hline
\end{tabular}


(Table 3 continued)

\begin{tabular}{|c|c|c|c|c|c|c|}
\hline \multirow{2}{*}{ Variables } & \multicolumn{2}{|c|}{ Model(4) } & \multicolumn{2}{|c|}{ Model(5) } & \multicolumn{2}{|c|}{ Model(6) } \\
\hline & Coefficient & Std. Error & Coefficient & Std. Error & Coefficient & Std. Error \\
\hline $\mathrm{C}$ & $\begin{array}{l}-2.8803 * * * \\
(-4.7215)\end{array}$ & 0.6100 & $\begin{array}{l}-2.8866^{* * * *} \\
(-4.7256)\end{array}$ & 0.6108 & $\begin{array}{l}-2.9355^{* * *} \\
(-4.8099)\end{array}$ & 0.6103 \\
\hline $\mathrm{TS}$ & $\begin{array}{l}-0.1424 * * * \\
(-5.7597)\end{array}$ & 0.0247 & $\begin{array}{l}-0.1411^{* * *} \\
(-5.7120)\end{array}$ & 0.0247 & $\begin{array}{l}-0.1406^{* * *} \\
(-5.6967)\end{array}$ & 0.0247 \\
\hline SS & $\begin{array}{l}-0.3241 * * \\
(-2.1775)\end{array}$ & 0.1488 & $\begin{array}{l}-0.2312 * * \\
(-2.4252)\end{array}$ & 0.0953 & $\begin{array}{l}-0.2329 * * \\
(-2.4481)\end{array}$ & 0.0951 \\
\hline LS & $\begin{array}{c}-0.0369 \\
(-1.4054)\end{array}$ & 0.0262 & $\begin{array}{c}-0.0202 \\
(-0.4789)\end{array}$ & 0.0422 & $\begin{array}{c}-0.0364 \\
(-1.3869)\end{array}$ & 0.0262 \\
\hline MS & $\begin{array}{l}-0.0645^{* *} \\
(-2.0161)\end{array}$ & 0.0320 & $\begin{array}{c}-0.0658^{*} \\
(-2.0497)\end{array}$ & 0.0321 & $\begin{array}{c}0.0342 \\
(0.3120)\end{array}$ & 0.1097 \\
\hline CR1 & $\begin{array}{c}-0.4062 \\
(-0.5866)\end{array}$ & 0.6925 & $\begin{array}{l}-0.4235 \\
(-0.6053)\end{array}$ & 0.6996 & $\begin{array}{c}-0.3601 \\
(-0.5211)\end{array}$ & 0.6911 \\
\hline CR10 & $\begin{array}{l}0.1765 * * * \\
(3.0896)\end{array}$ & 0.0571 & $\begin{array}{l}0.1763 * * * \\
(3.0780)\end{array}$ & 0.0573 & $\begin{array}{l}0.1773 * * * \\
(3.1060)\end{array}$ & 0.0571 \\
\hline $\mathrm{Z10}$ & $\begin{array}{c}-0.0237 \\
(-1.3469)\end{array}$ & 0.0176 & $\begin{array}{c}-0.0236 \\
(-1.3406)\end{array}$ & 0.0176 & $\begin{array}{c}-0.0236 \\
(-1.3395)\end{array}$ & 0.0176 \\
\hline \multicolumn{7}{|l|}{$\mathrm{CR} 1 \times \mathrm{CR} 1$} \\
\hline \multicolumn{7}{|l|}{$\mathrm{TS} \times \mathrm{TS}$} \\
\hline $\mathrm{SS} \times \mathrm{SS}$ & $\begin{array}{c}0.4088 \\
(0.8392)\end{array}$ & 0.4871 & & & & \\
\hline $\mathrm{LS} \times \mathrm{LS}$ & & & $\begin{array}{c}-0.0244 \\
(-0.4960)\end{array}$ & 0.0493 & & \\
\hline $\mathrm{MS} \times \mathrm{MS}$ & & & & & $\begin{array}{c}-0.1273 \\
(-0.9452)\end{array}$ & 0.1346 \\
\hline SIZE & $\begin{array}{l}0.1515^{* * *} \\
(5.2562)\end{array}$ & 0.0288 & $\begin{array}{l}0.1522 * * * \\
(5.2742)\end{array}$ & 0.0289 & $\begin{array}{l}0.1529 * * * \\
(5.3044)\end{array}$ & 0.0288 \\
\hline DA & $\begin{array}{l}-0.4076^{* * *} \\
(-6.3656)\end{array}$ & 0.0640 & $\begin{array}{l}-0.4080^{* * *} \\
(-6.3665)\end{array}$ & 0.0641 & $\begin{array}{l}-0.4101 * * * \\
(-6.4035) \\
\end{array}$ & 0.0640 \\
\hline INDUS & \multicolumn{2}{|c|}{ Yes } & \multicolumn{2}{|c|}{ Yes } & \multicolumn{2}{|c|}{ Yes } \\
\hline Adj. R2 & \multicolumn{2}{|c|}{0.5434} & \multicolumn{2}{|c|}{0.5425} & \multicolumn{2}{|c|}{0.5437} \\
\hline F-value & \multicolumn{2}{|c|}{$3.9056^{* * *}$} & \multicolumn{2}{|c|}{$3.8952 * * *$} & \multicolumn{2}{|c|}{$3.9099 * * *$} \\
\hline $\mathrm{D}-\mathrm{W}$ & \multicolumn{2}{|c|}{2.2213} & \multicolumn{2}{|c|}{2.2273} & \multicolumn{2}{|c|}{2.2272} \\
\hline
\end{tabular}

Notes: The F-test for fixed effects and the Hausman test for random effects both rejected the null hypothesis, and hence a fixed effect model is chosen for the study. T-statistics are reported in parentheses; ***,** and * indicate significance at the $1 \%, 5 \%$ and $10 \%$ levels, respectively.

Furthermore, we observed that the debt ratio of companies listed on the GEM board is relatively low at a level of about $17 \%$, which indicates that these companies mainly depend on equity capital and internal financing. The low debt ratio could also reveal that small and medium-sized enterprises are facing financing constraint to some extent.

\subsection{Results and Discussion}

We used Eviews 6.0 to conduct an overall regression on models (1) to (6) ${ }^{4}$. The results are presented in Table 3 . In Table 3 , we observe that the adjusted $\mathrm{R}^{2}$ of every model is about 0.55 , which indicates that the models have a good degree of fit. The significance of the F-values reported also shows good effectiveness of the regression overall for all models. In the models above, the relationship between ownership structure and the ROA of companies listed on the GEM board is significant. Furthermore, the Durbin-Watson (D-W) values for the models are all around 2.2 (relatively close to 2.0), indicating that there is no serious autocorrelation. Based on the regression results in Table 3 , the following extended analysis of model (1) to model (6) are provided:

\footnotetext{
${ }^{4}$ The panel data methodology employed in the study contributes to eliminating potential multicollinearity problems. Furthermore, correlation analyses executed before conducting the multiple regression analyses indicated that most cross-correlation for the independent variables is low $(<0.4)$ and that for CR1, CR10 and Z it is relatively high but still less than 0.8 , which reduced concerns about potential multicollinearity problems in the study.
} 


\subsubsection{Ownership Mix and Corporate Performance}

From model (1), we can deduce that the proportion of tradable shares, state-owned shares and managerial shares has a significant correlation with corporate performance, while the proportion of legal-person shares is not significant. According to model (3) to model (6), the nonlinear relationship between ownership mix and corporate performance is not significant except for the tradable shares, which has a quadratic nonlinear relationship with corporate governance.

Firstly, the proportion of tradable shares has a negative correlation with corporate performance at a $1 \%$ significance level, so hypothesis 1.1 is not rejected. At the same time, there is a quadratic nonlinear relationship between tradable shares and corporate performance, showing that we should not generalize the relationship between tradable shares and corporate performance while there is a reasonable interval.

Secondly, the proportion of state-owned shares has a negative correlation with corporate performance at a $5 \%$ significance level, so hypothesis 1.2 is not rejected. From the analysis above, we can conclude that the participation of state-owned shares may result in low management efficiency and is therefore not beneficial to the improvement of corporate performance. The conclusion, however, may have something to do with the general low proportion of state-owned shares of companies listed on the GEM board.

Thirdly, the proportion of managerial shares has a negative correlation with corporate performance at a $5 \%$ significance level, so hypothesis 1.4 is not rejected. There is a high proportion of managerial shares in companies listed on the GEM board. However, when the proportion has reached a certain level, the equity incentive behavior accelerates management to pursue corporate control instead, and at that point, a high managerial shares proportion is not beneficial to corporate governance, but could also affect corporate performance negatively.

Lastly, the proportion of legal-person shares has a negative correlation with corporate performance, so hypothesis 1.3 is rejected although the correlation is not statistically significant. From the analyses presented above, we know that legal-person shares have multipartite advantages compared with individual shares and state-owned shares. However, because the ultimate goal of legal-person shareholders is to maximize their own personal profit, it is inevitable for legal-person shareholders to sacrifice company interest for their own benefit. Moreover, the irregular operation, related party transaction and internal transaction would cause harm to market fairness and fair competition. All of these would cause unsatisfactory corporate performance.

\subsubsection{Ownership Concentration and Corporate Performance}

According to model (1) and model (2) in Table 3, the shareholding proportion of the top 10 largest shareholders has a significant positive correlation with corporate performance at a $1 \%$ significance level. There is no significant linear relation or U-shape relation between the largest shareholder and corporate performance. Furthermore, the effect of the $\mathrm{Z}$ index on corporate performance is found not to be significant. An extended analysis of ownership concentration and corporate performance is provided below:

Firstly, we can observe that there is a negative but insignificant correlation between the shareholding proportion of the largest shareholder and corporate performance, so hypothesis 2.1 can be supported to some extent. A potential reason why the relationship is not significant could be that the more equity the largest shareholder holds, the less counterbalancing this shareholder will experience in decision-making and behavior. This lack of counterbalancing can easily lead to decision-making error and could damage minority shareholders' interest, eventually harming the company's development.

Secondly, the shareholding proportion of the top 10 largest shareholders has a significant positive correlation with corporate performance, so hypothesis 2.2 is not rejected. This result indicates that certain forms of ownership concentration can avoid self-interested behavior to a certain degree and improves the accuracy and efficiency of decision-making in order to improve corporate performance. 
Lastly, the $\mathrm{Z}$ index has a negative correlation with corporate performance, so hypothesis 2.3 is rejected. The result shows that the counterbalancing of the largest shareholder does not benefit the improvement of corporate performance. The largest shareholder in companies listed on the GEM board may have extensive experience and a broad network, and have a dominant position in companies. Excessive counterbalance by the other large shareholders will influence the correctness and efficiency of the largest shareholder's decision-making, and his or her role to play, which is not favorable to company development.

Meanwhile, except for the industry variable, the other two control variables both have a significant correlation with corporate performance. Company size has a positive correlation with corporate performance, while the debt ratio exhibits a negative correlation with corporate performance.

\subsubsection{The Endogeneity of Ownership Structure}

Previous studies have shown that no serious endogeneity problem with regard to ownership structure is observed for Chinese companies (Cai \& Gao, 2010; Song, Zhang, \& Li, 2004). The current study used model (7) below to verify whether an endogeneity problem was detected for the companies included in this study.

$$
\mathrm{STO}_{\text {it }}=\alpha_{0}+\beta_{1} \mathrm{ROA}_{\text {it }}+\beta_{2} \mathrm{INDUS}_{\text {it }}+\beta_{3} \mathrm{SIZE}_{\text {it }}+\beta_{4} \mathrm{DA}_{\text {it }}+\varepsilon_{\text {it }}
$$

Where:

STO refers to variables of ownership structure. Owning to the space limitation, detailed results are not displayed here. The results, however, indicate that as a dependent variable, corporate performance has no significant relationship with ownership structure, that is, the endogeneity problem of ownership structure is not significant for companies listed on the GEM board.

\subsubsection{Robustness Test}

Model (8) below was constructed to test robustness by replacing ROA with return on equity (ROE) in model (1). The regression result is displayed in Table 4.

$$
\begin{aligned}
& R O E_{\text {it }}=\alpha_{0}+\beta_{1} \mathrm{TS}_{\text {it }}+\beta_{2} \mathrm{SS}_{i t}+\beta_{3} \mathrm{LS}_{\text {it }}+\beta_{4} \mathrm{MS}_{\mathrm{it}}+\beta_{5} \mathrm{CR} 1_{\mathrm{it}}+\beta_{6} \mathrm{CR} 10_{\mathrm{it}}+\beta_{7} \mathrm{Z}_{\mathrm{it}} \\
& +\beta_{8} \mathrm{INDUS}_{\mathrm{it}}+\beta_{9} \mathrm{SIZE}_{\mathrm{it}}+\beta_{10} \mathrm{DA}_{\mathrm{it}}+\varepsilon_{\mathrm{it}}
\end{aligned}
$$

Table 4. Regression of Ownership Structure and Corporate Performance (ROE)

\begin{tabular}{l|c|c|c}
\hline \multicolumn{1}{|c|}{ Variables } & Coefficient & Std. Error & T-value \\
\hline C & $-4.6735^{* * *}$ & 0.7533 & -6.2041 \\
\hline TS & $-0.1987^{* * *}$ & 0.0305 & -6.5130 \\
\hline SS & -0.1800 & 0.1174 & -1.5329 \\
\hline LS & -0.0213 & 0.0324 & -0.6572 \\
\hline MS & $-0.0664^{* *}$ & 0.0396 & -1.6775 \\
\hline CR1 & $-0.3922^{* *}$ & 0.8544 & -0.4591 \\
\hline CR10 & $0.1598^{* *}$ & 0.0706 & 2.2645 \\
\hline INDUS & -0.0288 & 0.0218 & -1.3254 \\
\hline SIZE & -0.0373 & 0.0244 & -1.5267 \\
\hline DA & $0.2420^{* * *}$ & 0.0356 & 6.7947 \\
\hline Adj. R $^{2}$ & $-0.5175^{* * *}$ & 0.0791 & -6.5388 \\
\hline F-value & & 0.4818 & \\
\hline D-W & & $3.5841^{* * *}$ & \\
\hline Nots: The & & 2.3284 & \\
\hline
\end{tabular}

Notes: The F-test for fixed effects and the Hausman test for random effects both rejected the null hypothesis, and hence a fixed effect model is chosen for the study. ${ }^{* *}, * *$ and $*$ indicate significance at the $1 \%, 5 \%$ and $10 \%$ levels respectively.

In Table 4, tradable shares have a significant correlation with corporate performance at a $1 \%$ significance level. Managerial shares have a weak correlation with corporate performance at a $10 \%$ significance level, while the results 
provide no support for state-owned shares and legal-person shares. As for ownership concentration, the shareholding proportion of the top 10 largest shareholders has a positive correlation with corporate performance at a $5 \%$ significance level, while the shareholding proportion of the largest shareholder and the $\mathrm{Z}$ index are not significant. The regression results of model (8) are similar to model (1), which indicates the robustness of the relationship between ownership structure and financial performance in the context of the Chinese GEM board for different estimations of performance.

\section{CONCLUSIONS AND SUGGESTIONS}

Taking 153 companies listed on the GEM board as research objects, the study reported here studied the relationship between ownership structure and corporate performance with the empirical analysis of data from 2010 to 2012 . Our findings show that the proportion of state-owned shares and managerial shares has a negative correlation with corporate performance, that is, the higher these ownership proportions are, the worse the corporate performance becomes. In addition, tradable shares have a quadratic nonlinear correlation with corporate performance, and the relationship between legal-person shares and corporate performance is not significant. As for the relationship between ownership concentration and corporate performance, we found that only the share proportion of the top 10 largest shareholders has a significant positive correlation with corporate performance, while the relationships between the share proportion of the largest shareholder and corporate performance, and those between the $\mathrm{Z}$ index and corporate performance, are not significant. Based on these conclusions, some suggestions for the development of listed companies on the GEM board are provided below.

Firstly, institutional investors should be introduced. Presently, the majority of the tradable shareholders in China are individual investors, with the small and scattered characteristics of individual investors leading to their speculative behavior. Compared with individual investors, institutional investors have abundant capital, professional teams and more information channels, so their investing behavior is more rational and their investment cycle is more stable, which enables institutional investors to be both capable and motivated to monitor the companies they are investing in. Institutional investors' involvement could also impel companies listed on the GEM board to optimize ownership structure and to improve corporate performance, should contribute to the stable and efficient operation of the GEM board and capital market.

Secondly, managerial shares should be allocated prudently. According to the results, it is obvious that managerial shares have a significant negative correlation with corporate performance. Listed companies should therefore treat stock incentives to management-level employees seriously. At the same time, companies need to build sound supervision mechanisms, aiming at effectively avoiding the negative effects associated with managerial shares.

Lastly, an appropriate ownership concentration and degree of balance for majority shareholders should be maintained. From the results, we can learn that companies should keep the proportion of majority shareholders in control to avoid individual extreme behavior and the domination of a single shareholder, to protect the interest of minority shareholders. Meanwhile, companies should optimize the proportion of shareholders to let ownership concentration be kept at an appropriate level so that the largest shareholder can play his or her role.

In addition, companies listed on the GEM board should take expanding their size and maintaining an appropriate debt ratio into consideration to promote their performance.

\section{AUTHOR BIOGRAPHIES}

Qiaowen Zhang is a PhD student in the Department of Business Management at Stellenbosch University (South Africa), and she is also a lecturer at the China-Africa International Business School at Zhejiang Normal University (China). Her research interests include corporate governance, institutional investors, entrepreneurial management, and China-Africa finance cooperation. E-mail: zhangqiaowencam@126.com

Pierre Erasmus is Professor of Financial Management in the Department of Business Management at Stellenbosch University (South Africa). His research interests include value-based financial management, investor short-termism, capital structure theory and corporate valuation. E-mail: pde@sun.ac.za 


\section{REFERENCES}

Anderson, R. C., \& Reeb, D. M. (2003). Founding-family ownership and firm performance: Evidence from the S\&P 500. Journal of Finance, 58, 1301-1328.

Bai, C. E., Liu, Q., Lu, Z., Song, M., \& Zhang, J. X. (2005). An empirical study on Chinese listed firms' corporate governance. Economic Research Journal, 2, 81-91.

Berle, A. A., \& Means, G. C. (1932). The Modern Corporation and Private Property. New York: The Macmillan Company.

Brown, L. D., \& Caylor, M. L. (2009). Corporate governance and firm operating performance. Review of Quantitative Finance and Accounting, 32, 129-144.

Cai, W. X., \& Gao, M. H. (2010). Ultimate owner's ownership, control rights and expropriation: Evidence from related-party transactions. South China Journal of Economics, 2, 28-41.

Chen, D. P., \& Chen, Y. S. (2011). Research on relationship among ownership concentration, ownership balance and corporate performance: An empirical examination of listed companies on the SME board from 2007 to 2009. Accounting Research, 1, 38-43.

Chen, X. Y., \& Xu, X. D. (2001). Equity structure, firm performance and the protection for investors' interest. Economic Research Journal, 11, 3-11.

Cornett, M. M., Marcus, A. J., \& Tehranian, H. (2008). Corporate governance and pay-for-performance: The impact of earnings management. Journal of Financial Economics, 2, 357-373.

Demsetz, H., \& Villalonga, B. (2001). Ownership structure and corporate performance. Journal of Corporate Finance, 7, 209233.

Du, Y., \& Liu, L. G. (2002). Ownership structure and corporate governance efficiency: Empirical evidence from Chinese listed companies. Management World, 11, 124-133.

Fama, E., \& Jensen, M. (1983). Separation of ownership and control. Journal of Law and Economics, 2, 301-325.

Fernandez, C., \& Gomez, S. (2002). Does ownership structure affect firm performance? Evidence from a continental-type governance system. Working Paper.

Gorton, G., \& Schmid, F. A. (2000). Universal banking and the performance of German firms. Journal of Financial Economics, $1,29-80$.

Gugler, K., Mueller, D. C., \& Yurtoglu, B. B. (2004). Corporate governance and the return on investment. Journal of Law and Economics, 2, 589-633.

Gursoy, G., \& Aydogan, K. (2002). Equity ownership structure, risk taking, and performance. Emerging Markets, Finance and Trade, 6, 6-25.

Holderness, C. G., \& Sheehan, D. P. (1988). The role of majority shareholders in publicly held corporations. Journal of Financial Economics, 20, 317-346.

Hu, G. L., \& Jiang, G. Z. (2004). Ownership structure, corporate governance and performance: New evidence from the listed companies in China. Finance and Trade Research, 4, 83-89.

Jensen, M., \& Meckling, W. (1976). Theory of the firm: managerial behavior, agency costs and ownership structure. Journal of Financial Economics, 3, 305-360.

Kong, A. G., \& Wang, S. Q. (2003). The influence of ownership structure on corporate performance: An empirical study of China's listed companies. Fudan Journal (Social Sciences), 5, 26-33.

Li, Z. L., \& Wu, S. (2010). Ownership structure, board governance and corporate growth. Economy and Management, 5, 28-34.

Lin, Z. G., Xu, H., \& Tang, L. (2009). Shareholding structure, disclosure of internal control \& enterprise value. Collected Essays on Finance and Economics, 1, 68-74.

Lins, K., \& Servaes, H. (2002). Is corporate diversification beneficial in emerging markets? Financial Management, 31, 5-31.

Liu, G. L., \& Wang, J. S. (2000). Positive analysis of listed companies: Equity structures, incentive systems, and performances. Economic Theory and Business Management, 5, 40-45.

Liu, X. X. (2000). The impact of the structure of China industrial enterprise's ownership on its efficiency. Economic Research Journal, 2, 17-25.

Liu, Y. G., \& Gao, Y. N. (2007). Study on relationship between ownership balance and corporate performance of Chinese listed companies. Journal of Sun Yatsen University, 4, 102-108.

Liu, Y. Y., Huang, Z. X., Tse, E., \& He, X. F. (2011). Empirical research on shareholding structure and corporate performance of Chinese listed companies. Research on Economics and Management, 2, 24-32.

Liu, Z. B. (2004). Study on capital structure and corporate performance of listed companies. Beijing: China Financial and Economic Publishing House.

McConnell, J., \& Servaes, H. (1990). Additional evidence on equity ownership and corporate value. Journal of Financial Economics, 27, 595-612.

Pedersen, T., \& Thomsen, S. (1999). Economic and systemic explanations of ownership concentration among Europe's largest companies. International Journal of the Economics of Business, 6, 367-381.

She, J. H., \& Hu, J. (2007). Positive analysis on ownership structure and corporate performance relationships for listed companies. Modern Economic Science, 1, 99-107.

Shleifer, A., \& Vishny, R. (1986). Large shareholders and corporate control. Journal of Political Economy, 3, 461-488. 
Song, M., Zhang, J. X., \& Li, C. T. (2004). A trap in the ownership structure for listed companies. Nankai Business Review, 1, 923.

Su, D. W., \& He, X. X. (2012). Ownership structure, corporate governance and productive efficiency. Journal of Productivity Analysis, 3, 303-318.

Sun, Y. X., \& Huang, Z. H. (1999). Ownership structure and corporate performance of Chinese listed companies. Economic Research Journal, 12, 23-30.

Switzer, L. N. (2007). Corporate governance, Sarbanes-Oxley small-cap firm performance. Quarterly Review of Economics and Finance, 5, 651-666.

Tan, Q. M., He, J., \& Ma, J. (2011). Board composition, ownership structure and firm performance. Journal of Finance and Economics, 5, 16-33.

Thomsen, S., \& Pedersen, T. (2000). Ownership structure and economic performance in the largest European companies. Strategic Management Journal, 6, 689-705.

Wahla, K-U-R., Shah, Z. A., \& Hussain, Z. (2012). Impact of ownership structure on firm performance evidence from nonfinancial companies at Karachi Stock Exchange. International Research Journal of Finance and Economics, 84, 6-13.

Wang, X. H., \& Xu, J. (2009). Listed companies' ownership structure, capital structure and corporate performance under different growth opportunities: An empirical study based on China listed companies in distribution industry. Journal of Business Economics, 7, 20-28.

Wu, S. K. (2002). Ownership structure and firm performance: An empirical research on Chinese public companies. China Industry Economics, 1, 80-87.

Xu, E. M., \& Wang, Z. H. (2000). On relation between the corporate governance of China's public companies and their strategic performance. Nankai Management Review, 4, 4-14.

$\mathrm{Xu}, \mathrm{W} .$, \& Hu, D. Y. (2006). Equity ownership structure and corporate performance: An empirical study from the perspective of relative Tobin Q. Journal of Nanjing Normal University, 1, 59-64.

$\mathrm{Xu}, \mathrm{X}$. N., \& Wang, Y. (1999). Ownership structure and corporate governance in Chinese stock companies. China Economic Review, 10, 75-98.

Xu, X. Y., \& Zhang, L. D. (2008). Relations between ownership structure and corporate value - a subgroup text result. China Industry Economics, 4, 102-109.

Yan, R. S. (2009). A study on the relationship between ownership structure and corporate performance. Research on Financial and Economic Issues, 6, 80-83.

Yu, D. Z. (2001). Ownership structure, governance efficiency and corporate performance. China Industry Economics, 5, 54-62.

Zhang, C., \& Fang, P. (2009). An empirical study on relationship between performance and ownership structure of private listed companies. Journal of Shanghai University (Social Sciences), 2, 90-105.

Zhang, H. J. (2000). Theoretical and empirical analysis on ownership structure and corporate performance of Chinese listed companies. Economic Science, 4, 34-44.

Zhang, J. X., \& Zhang, H. (2004). Corporate performance, market value and governance structure of private listed companies. The Journal of World Economy, 11, 1-13. 


\section{NOTES}

